\title{
EVALUATION OF CROP AND IRRIGATION WATER REQUIREMENTS FOR SOME SELECTED CROPS IN APULIA REGION -SOUTHERN ITALY
}

\author{
${ }^{1}$ Mohannad Alobid, ${ }^{2}$ Szúics István \\ ${ }^{1}$ University of Debrecen, Károly Ihrig Doctoral School of Management and Business, \\ Department of Applied Economic and Science \\ ${ }^{2}$ University of Debrecen, Department of Applied Economic and Science
}

${ }^{1}$ Mohannad.alobid@econ.unideb.hu,

${ }^{2}$ Szucs.istvan@econ.unideb.hu

\begin{abstract}
Nowadays, nearly $90 \%$ of global water consumption is caused by irrigation activities, and more than $40 \%$ of the crops are produced under irrigated conditions. This study is an endeavour to estimate the irrigation water requirement (IWR) and crop water requirement (CWR) for some selected crops (Pepper, Eggplant, Potato, Soybean, Maize, Wheat Melon, Lettuce, Sunflower, Broadbean, Citrus, Cherry, Olive tree, Sugarbeet, Artichoke, Wine Grapes, Carrot...etc.) in Sothern Italy. The selected districts (Sant' Arcangelo) have been taken as a case study area. Demanded meteorologically (rainfall, temperature, humidity, wind speed, sunshine hours) and crop data (crop coefficient and crop calendar) have been collected for 30 years period from 1981 to 2011. FAO CROPWATv8.0 software has been applied for requisite calculation of CWR and IWR along with the developing of cropping patterns. The FAO Penman-Monteith equation is used for estimating the reference evapotranspiration (ETO) by using meteorological data in the framework of CROPWAT model as it regarded as a good evaluator for a wide variety of climatic conditions. The analysis indicates that FAO Penman-Monteith suits very well for the study area and can be successfully used for the estimation of reference evapotranspiration. The important results in this study indicate that the IWR is very low from November to April (wintertime) due to higher rainfall intensity in these months and from month May to October a considerable amount of water is required for irrigation.
\end{abstract}

Keywords: Irrigation Water Requirement, Crop Water Requirement, FAO Penman-Monteith, CROPWAT. (JEL Classification: Q25, Q24,Q10 )

\section{INTRODUCTION}

Agriculture is expected to feed an estimated population of over 9 billion people by the year 2050 through a $50 \%$ increase over the current food production level, with $80 \%$ of the increase stemming from production intensification which is essentially possible thanks to irrigation (Report, 2017). At the same time, agriculture is responsible for about $70 \%$ of the total water withdrawals worldwide and it is the first sector to be put under significant pressure due to increasing water scarcity (Hanjra \& Qureshi, 2010). Information needs for agricultural decision making at all levels are increasing quickly due to increased demands for agricultural products and increased pressures on land, water, and other natural resources(Bruinsma, 2009). The agricultural sector is the most water-consuming in the world, reaching more than $70 \%$ of the withdrawal in many areas of the world and especially in the Southern Mediterranean countries, on the other hand in many countries, particularly those situated in the arid and 
semi-arid regions of the world, this dependency can be expected to intensify, due to the increasing demand for agricultural products(Dubois, 2011). Thus, the contribution of irrigated agriculture to food production is substantial and the expansion of irrigated agriculture will surely result in higher yield and production. According to it, irrigation is required to satisfy the water demand during the driest periods of the year, especially in the semi-arid Mediterranean climate (R. G. Allen, L. S. Pereira, D. Raes, \& M. J. F. Smith, Rome, 1998).

Climate change has previously caused significant impacts on water resources, hydropower, food security, human health particularly for African nations, along with the entire world (Magadza \& Assessment, 2000). Studies on climate impacts like (temperature, precipitation, rainfall, evapotranspiration, and soil characteristics) and adaptation strategies are progressively becoming main areas of scientific concern, e.g. impacts on the production of crops such as wheat and rice (Aggarwal, Kalra, Chander, \& Pathak, 2006; Dhungana, Eskridge, Weiss, \& Baenziger, 2006; Gbetiobouo, Hassan, \& Agricultural Sciences, 2004; Hoogenboom \& meteorology, 2000), industry (Harle, Howden, Hunt, \& Dunlop, 2007) and the natural landscape (Dockerty et al., 2006). water resources in the river basin catchments (Chang, Knight, Staneva, \& Kostov, 2002; Herrera $\square$ Pantoja \& Hiscock, 2008; Wilby \& Harris, 2006), crop productivity and soil water balance have been studied with crop growth models by using parameters from different climate models (Kang, Khan, \& Ma, 2009; Stöckle, Donatelli, \& Nelson, 2003).

The objectives of this study are to estimate the CWR which are " the depth of water [mm] needed to meet the water consumed through evapotranspiration (ETc) by a disease-free crop, growing in large fields under nonrestricting soil conditions including soil water and fertility, and achieving full production potential under the given growing environment" (Pereira \& Alves, 2005). In addition to evaluate the IWR based on soil and water resources to assess of the irrigation potential (Margat, Frenken, \& Faurès, 2005) and developed cropping pattern in the study area for the selected crops to ensure the optimum use of available irrigation water and on the other hand to Estimate if there is a Salinity problem on the study area.

\section{METHODOLOGY}

In this study we estimate the CWR and IWR and to developed cropping pattern in the study area for the selected crops to confirm the optimum use of available irrigation water and the optimum use of the available land. Thus, assessment of evapotranspiration loss, effective rainfall and the percentage of the total area covered by each crop are very essential. Once more, to ensure the minimum loss of irrigation water crop coefficient at different stages with their stage lengths and various climatic parameters are adjusted for the study areas we start with the description of the study area.

\section{Description of the study area :}

The project area, Sant' Arcangelo, located in the municipality of Sannicandro, province of Bari in the Apulia region (Southern Italy), at approximately $40.99^{\circ} \mathrm{N}$ latitude and $16.80^{\circ} \mathrm{E}$ longitude with an average altitude about $183 \mathrm{~m}$ above sea level. The study area is characterised by semi-arid Mediterranean climatic conditions, with hot and dry summer season and moderately cold and wet winter.

The total gross surface area under consideration is about 164 ha, of which $7 \%$ is occupied by roads and buildings, which reduce the net irrigable area to 153 ha. Major land use is for agricultural purposes: olives, orchards, almonds and horticultural crops are widespread, and, in some areas, high quality vineyards can be found. The location of study area is shown in figure 1 .

Figure 1. Location of the study area in Apulia region

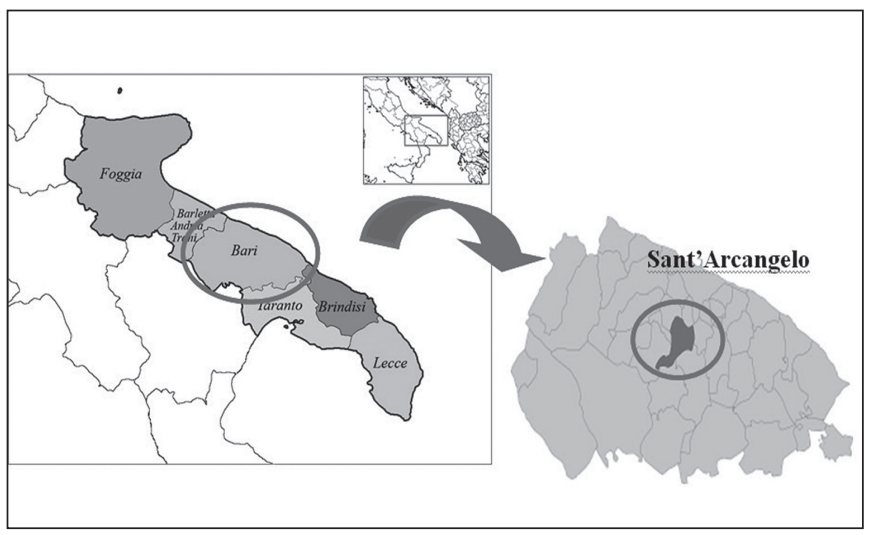

Data collections and Data Processing

\section{Crop water requirements}

Crop water requirement can be defined as the amount of water needed to maintain an optimal moisture condition in the crop rooting depth, to compensate for water lost mainly through the process of evapotranspiration (ET). The main factors affecting ET are the weather parameters, crop characteristics, management and environmental conditions. Crop water requirement and net irrigation requirements are calculated through the following steps:

- Estimation of reference evapotranspiration (ETo) using climatic data of project area.

- Estimation of crop evapotranspiration (ETc) considering crop coefficient $(\mathrm{Kc})$ and reference evapotranspiration.

- Determination of effective precipitation (Peff) from the precipitation data for the specific area.

- Estimation of net irrigation requirement (NIR) as a difference between Crop evapotranspiration and effective precipitation.

CROPWAT is a program developed by the Land and Water Development Division of FAO for the calculation of crop water requirements and irrigation requirements 
based on soil, climate and crop data. In addition, the program allows the development of irrigation schedules for different management conditions and the calculation of scheme water supply for varying crop patterns. CROPWAT can also be used to evaluate farmers' irrigation practices and to estimate crop performance under both rainfed and irrigated conditions.

\section{Cropping pattern}

According to soil and climate data given for our project area, the following crops (21) are taken into consideration for the determination of crop water requirements and cropping pattern :

- Tree crops: citrus, olives, peach, cherry and grapes.

- Field crops: sugar-beet, wheat, sunflower, maize and soybean.

- Horticultural crops: tomato, eggplants, potato, lettuce, pepper, carrots, watermelon and Artichoke.

The main crops growing parameters are given in table 1 as they were used in CROPWAT software for the estimation of crop water requirements, irrigation requirements and crop response to water curves.

\section{Crop coefficient $(\mathrm{Kc})$}

Crop coefficient Kc is the ratio of ETc to the reference ETo and it expresses the difference in evapotranspiration between the cropped area and the reference grass surface. This coefficient combines differences in soil evaporation and crop transpiration rate between the crop and the reference grass surface (FAO, 2004).

Kc represents an integration of four primary characteristics, which distinguish the crop from reference grass which has a constant appearance and a complete ground cover:

I Crop height

II Canopy resistance

III Albedo of solar radiation from the exposed soil

IV Evaporation from exposed soil.

Factors determining the crop coefficient are: Climate (arid climate and higher windy speed- greater Kc), Soil evaporation (depends on soil wetness), Crop type (taller crops and closer spacing-greater $\mathrm{Kc}$ ) and Crop growth stages (initial, crop development, mid-season, and late season).

Mean monthly crop coefficients (Kc) for fully grown crops, are given in Table2 elaborated at the University of Bari and adjusted by CIHEAM-IAMB, represent average values in the Apulia conditions.

Table 1. The main crop growing parameters : Kc, root depth, development stages, depletion fraction, yield response function and crop height

\begin{tabular}{|c|c|c|c|c|c|c|c|c|c|c|c|c|c|c|c|c|c|}
\hline \multirow{2}{*}{\multicolumn{2}{|c|}{\begin{tabular}{|c|} 
\\
Crop \\
characteristics
\end{tabular}}} & \multicolumn{16}{|c|}{ Crop } \\
\hline & & \multirow{2}{*}{\begin{tabular}{|c|} 
Citrus \\
0,75 \\
\end{tabular}} & \multirow{2}{*}{\begin{tabular}{|c|} 
Cotton \\
0,35
\end{tabular}} & \multirow{2}{*}{$\begin{array}{r}\text { Faba } \\
\text { Bean } \\
0,5\end{array}$} & \multirow{2}{*}{$\begin{array}{c}\text { Grapes } \\
0,3\end{array}$} & \multirow{2}{*}{$\begin{array}{c}\text { Maize } \\
0,3\end{array}$} & \multirow{2}{*}{\begin{tabular}{|l|} 
Olive \\
0,65
\end{tabular}} & \multirow{2}{*}{$\begin{array}{l}\text { Peach } \\
0,55\end{array}$} & \multirow{2}{*}{\begin{tabular}{|c|} 
Pepper \\
0,6 \\
\end{tabular}} & \multirow{2}{*}{$\begin{array}{c}\text { Potato } \\
0,5\end{array}$} & \multirow{2}{*}{$\begin{array}{c}\text { Spring } \\
\text { Wheat } \\
0,3\end{array}$} & \multirow{2}{*}{$\begin{array}{c}\text { Sugar } \\
\text { Beet } \\
0,35\end{array}$} & \multirow{2}{*}{$\begin{array}{c}\begin{array}{c}\text { Sun- } \\
\text { flower }\end{array} \\
0,35\end{array}$} & \multirow{2}{*}{$\begin{array}{c}\text { Tomato } \\
0,6\end{array}$} & \multirow{2}{*}{$\begin{array}{r}\text { Water } \\
\text { Melon } \\
0,4\end{array}$} & \multirow{2}{*}{\begin{tabular}{|c} 
Winter \\
Barley \\
0,3
\end{tabular}} & \multirow{2}{*}{$\begin{array}{r}\text { Winter } \\
\text { Wheat } \\
0,7\end{array}$} \\
\hline & I & & & & & & & & & & & & & & & & \\
\hline \multirow[t]{2}{*}{$\mathrm{Kc}$} & II & 0,7 & 1,2 & 1,15 & 0,85 & 1,2 & 0,45 & 0,9 & $\begin{array}{l}1,05 \\
115\end{array}$ & 1,15 & 1,15 & 1,2 & 1,15 & 1,15 & 1 & 1,15 & 1,15 \\
\hline & II & 0,75 & 0,7 & 1,1 & 0,45 & 0,6 & 0,65 & 0,65 & 0,9 & 0,75 & 0,25 & 0,85 & 0,35 & 0,8 & 0,75 & 0,25 & 0,25 \\
\hline \multirow{2}{*}{$\begin{array}{c}\text { Root. } \\
\text { depth (m) }\end{array}$} & Initial & 1,2 & 0,3 & 0,3 & 1,5 & 0,3 & 1,5 & 1,5 & 0,25 & 0,3 & 0,3 & 0,3 & 0,3 & 0,3 & 0,3 & 0,3 & 0,3 \\
\hline & Total & 1,2 & 1,4 & 0,7 & 1,5 & 1,5 & 1,5 & 1,5 & 0,8 & 0,6 & 1,2 & 1 & 1,3 & 1,2 & 1 & 1 & 1 \\
\hline \multirow{3}{*}{$\begin{array}{l}\text { Depletion } \\
\text { fraction }\end{array}$} & I & 0,5 & 0,65 & 0,45 & 0,35 & 0,55 & 0,65 & 0,5 & 0,3 & 0,35 & 0,55 & 0,55 & 0,55 & 0,4 & 0,4 & 0,55 & 0,55 \\
\hline & II & 0,5 & 0,65 & 0,45 & 0,35 & 0,55 & 0,65 & 0,5 & 0,3 & 0,35 & 0,55 & 0,55 & 0,55 & 0,4 & 0,4 & 0,55 & 0,55 \\
\hline & II & 0,5 & 0,65 & 0,45 & 0,35 & 0,55 & 0,65 & 0,5 & 0,3 & 0,35 & 0,55 & 0,55 & 0,55 & 0,4 & 0,4 & 0,55 & 0,55 \\
\hline \multirow{5}{*}{$\begin{array}{l}\text { Yield } \\
\text { Response } \\
\text { function }\end{array}$} & I & 1,2 & 0,2 & 0,2 & 0,85 & 0,4 & 0,7 & 1,1 & 1,4 & 0,45 & 0,2 & 1 & 0,2 & 0,4 & 0,45 & 0,2 & 0,2 \\
\hline & II & 1,2 & 0,2 & 0,2 & 0,85 & 0,4 & 0,7 & 1,1 & 0,6 & 0,8 & 0,2 & 1 & 0,5 & 0,4 & 0,7 & 0,6 & 0,6 \\
\hline & II & 1,2 & 0,5 & 0,85 & 0,85 & 1,5 & 0,7 & 1,1 & 1,2 & 0,7 & 0,65 & 1 & 0,9 & 1,1 & 0,8 & 0,5 & 0,5 \\
\hline & IV & 1,2 & 0,25 & 0,2 & 0,85 & 0,5 & 0,7 & 1,1 & 0,6 & 0,2 & 0,55 & 1 & 0,9 & 0,6 & 0,3 & 0,4 & 0,4 \\
\hline & Total & 1,2 & 0,85 & 1,05 & 0,85 & 1,25 & 0,7 & 1,1 & 1,1 & 1,1 & 1,15 & 1 & 0,95 & 1,05 & 1,1 & 1 & 1,05 \\
\hline \multicolumn{2}{|c|}{ Crop Height (m) } & 1,5 & 1,4 & 0,8 & 1,2 & 2 & 3 & 3 & 0,7 & 0,6 & 1 & 0,7 & 1,5 & 0,6 & 0,4 & 1 & 1 \\
\hline
\end{tabular}


Table 2. Mean monthly crop coefficient (Kc) values for ETc estimate of some important crops grown in Southern Italy

\begin{tabular}{|c|c|c|c|c|c|c|c|c|c|c|c|c|}
\hline \multirow{3}{*}{ Crops } & \multicolumn{12}{|c|}{ Month } \\
\hline & Jan & Feb & Mar & Apr & May & Jun & Jul & Aug & Sep & Oct & Nov & Dec \\
\hline & \multicolumn{12}{|c|}{ Tree Crops } \\
\hline Citrus & 0,75 & 0,75 & 0,7 & 0,7 & 0,7 & 0,65 & 0,65 & 0,65 & 0,65 & 0,65 & 0,7 & 0,7 \\
\hline Cherry & - & - & - & 0,75 & 0,9 & 0,95 & 0,95 & 0,9 & 0,86 & - & & - \\
\hline Olive tree & 0,5 & 0,5 & 0,5 & 0,5 & 0,5 & 0,5 & 0,5 & 0,5 & 0,5 & 0,5 & $0,, 5$ & 0,5 \\
\hline Peach & - & - & 0,53 & 0,71 & 0,81 & 0,86 & 0,86 & 0,84 & 0,78 & on & & - \\
\hline Grapevine & - & - & - & 0,48 & 0,59 & 0,68 & 0,68 & 0,68 & 0,68 & - & & - \\
\hline \multicolumn{13}{|c|}{ Vegetables Crops } \\
\hline $\begin{array}{l}\text { "Autumn Sugar } \\
\text { Beet" }\end{array}$ & 0.5 & 0,5 & 0,5 & 0,87 & 1,20 & 1,30 & 1,30 & - & - & - & 0,4 & 0,4 \\
\hline $\begin{array}{l}\text { Spring Sugar } \\
\text { Beet }\end{array}$ & - & 0,35 & 0,62 & 1,10 & 1,20 & 1,24 & 1,24 & 0,95 & - & - & - & - \\
\hline Artichoke & 1.25 & 115 & 095 & - & - & - & 0,6 & 0,7 & 08 & 105 & 1,22 & 1,3 \\
\hline Carrot & - & - & - & - & - & - & 0,4 & 0,7 & 0,9 & 1 & 1,05 & 1,00 \\
\hline $\begin{array}{l}\text { "Cereals (durum } \\
\text { wheat)" }\end{array}$ & 0.8 & 10 & 11 & 115 & 085 & 035 & - & - & - & - & 0,4 & 0,6 \\
\hline Broad bean & 08 & 09 & 095 & 095 & 09 & - & - & - & & - & 0,4 & 0,65 \\
\hline Sunflower & - & - & - & 04 & 085 & 1,20 & 1,02 & 0,45 & - & - & & \\
\hline Lettuce & 1 & 1 & 09 & - & - & - & - & - & - & - & 0,75 & 0,9 \\
\hline Maize & - & - & - & 0,45 & 0,6 & 1,05 & 1,2 & 0,6 & & - & & \\
\hline Eggplant & - & - & - & 0,30 & 0,45 & 0,7 & 1 & 1,15 & 1,00 & - & & - \\
\hline Early Potato & 0,5 & 0,8 & 1,1 & 1,15 & 0,9 & - & - & - & - & - & - & - \\
\hline $\begin{array}{l}\text { "Common } \\
\text { Potato" }\end{array}$ & - & - & 0,5 & 0,8 & 1,1 & 1,15 & - & - & - & - & - & - \\
\hline Tomato & - & - & - & 0,5 & 0,87 & 1,2 & 1,1 & 0,8 & - & - & - & - \\
\hline Pepper & - & - & - & 0,64 & 0,75 & 1 & 1 & 0,8 & - & - & - & - \\
\hline Soya & - & - & - & 0,4 & 0,51 & 0,9 & 1 & 0,4 & - & & - & \\
\hline Watermelon* & - & - & - & 0,45 & 0,85 & 1 & 0,8 & - & - & - & - & - \\
\hline
\end{tabular}

\section{Reference Evapotranspiration (ET0)}

Reference evapotranspiration represents the amount of water lost by evapotranspiration process from "a hypothetical reference crop with an assumed crop height of $0.12 \mathrm{~m}$, a fixed surface resistance of $70 \mathrm{~s} / \mathrm{m}$ and an albedo of 0.23 " and maintained under optimal water and nutrient conditions (FAO 56, 2004).

The reference surface closely resembles on extensive grass surface of uniform height, actively growing, completely shading the ground and with adequate water content. The requirements that the grass surface should be extensive and uniform result from the assumption that all energy fluxes are one-dimensional upwards. The fixed surface resistance of 70 $\mathrm{s} / \mathrm{m}$ implies a moderately dry soil surface resulting from about a weekly irrigation frequency.

$\mathrm{ET}_{\mathrm{o}}$ provides a standard to which: (i) ET at different periods of the year or the other regions can be compared, and (ii) ET of other crops can be related.

There are numerous methods for estimation of reference evapotranspiration. They all rely on climatic parameters. The most commonly used methods are FAO Penman-Monteith, Hargreaves-Samani, and FAO Penman-Monteith with only measured air temperature data.

\section{FAO Penman-Monteith method}

The Penman-Monteith approach is a reliable physicallybased method. This method is recommended as a standard method for the estimation of reference evapotranspiration. It shows the best performance under both humid and arid conditions. The main climatic factors required for this equation are air temperature, humidity, wind speed and solar radiation.

Although, many areas of the world have few meteorological stations that measure all of these variables, the cost of such stations is decreasing, and it is likely that use of PenmanMonteith approach will spread even to developing regions. Knowing that a standard set of measured input data is available, the reference evapotranspiration (ETo) can be calculated by the standardized form of the Penman-Monteith equation (1): 
$E T_{0}=\frac{0.408 \Delta\left(R_{n}-G\right) \frac{}{T+273} u_{2}\left(e_{s}-e_{a}\right)}{\Delta+\gamma\left(1+0.34 u_{2}\right)}$

where:

- $\mathrm{ET}_{\mathrm{o}}$, the reference evapotranspiration $\left(\mathrm{mm} \mathrm{day}^{-1}\right)$

- $\mathrm{R}_{\mathrm{n}}$, the net radiation $\left(\mathrm{MJ} \mathrm{m}^{-2}\right.$ day $\left.^{-1}\right)$

- $\mathrm{G}$, the soil heat flux density $\left(\mathrm{MJ} \mathrm{m}^{-2} \mathrm{day}^{-1}\right)$

- $\mathrm{T}$, the mean daily air temperature at $2 \mathrm{~m}$ height $\left({ }^{\circ} \mathrm{C}\right)$

- $\Delta$, the slope of the saturated vapour pressure curve $\left(\mathrm{kPa}^{\circ} \mathrm{C}^{-1}\right)$

- $\gamma$, the psychrometric constant $\left(66 \mathrm{~Pa}^{\circ} \mathrm{C}^{-1}\right)$

- $\mathrm{e}_{\mathrm{s}}$, the saturated vapour pressure at air temperature $(\mathrm{kPa})$

- $e_{a}$, the actual vapour pressure $(\mathrm{kPa})$

- $\mathrm{U}_{2}$, the wind speed measured at $2 \mathrm{~m}$ height $\left(\mathrm{m} \mathrm{s}^{-1}\right)$

FAO Penman-Monteith method with only measured air temperature data

This method is recommended by the FAO when only air temperature data are available. The equation used for the estimation of reference evapotranspiration is the same as in the case of standard Penman-Monteith approach, explained previously. However, the missing weather parameters have to be estimated.

Wind speed is fixed to $2 \mathrm{~m} / \mathrm{s}$ (average value of 2000 weather stations around the globe); more accurate data could be used when available.

Solar radiation is estimated as Equation (2):

$\mathrm{Eq}(2)$

Where:

- $\mathrm{K}_{\mathrm{Rs}}$, empirical radiation adjustment coefficient, between 0.16 for "interior" and 0.19 for "coastal" areas

$R_{s}=k_{R s} \sqrt{\left(T_{\max }-T_{\min }\right)} R_{a}^{\bullet}$ and $\mathrm{T}_{\max }$ and $\mathrm{T}_{\min }$ minimum maximum temperature $\left({ }^{\circ} \mathrm{C}\right)$

- $\mathrm{R}_{\mathrm{a}}$, extra-terrestrial radiation $\left(\mathrm{MJ} \mathrm{m}^{-2}\right.$ day $\left.^{-1}\right)$

Assuming that $\mathrm{T}_{\text {dew }}$ is close to $\mathrm{T}_{\text {min }}$ at a reference site (at sunrise), actual vapour pressure $\left(\mathrm{e}_{\mathrm{a}}\right.$ ) is estimated as Equation (3):

Eq (3)

The mean saturation vapor pressure (es) is computed as the average between the saturation vapor pressure at maximum and minimum air temperature.

$e_{a}=e^{o}\left(T_{\min }\right)=0.611 \exp \left[\frac{17.27 T_{\min }}{T_{\min }+237.3}\right] C R O P W A T$

software for the estimation of crop water requirements and irrigation scheduling
CROPWAT software (version 8.0 for Windows), developed by the FAO, is used to estimate ETc and simulate various irrigation scenarios considering optimal and limiting water supply. CROPWAT is a computer program for the calculation of crop water requirements and irrigation scheduling based on soil, climate and crop data.

Reference evapotranspiration, estimated by CROPWAT, uses the FAO Penman-Monteith approach when only air temperature data were available. The results of estimation of weather variables and reference evapotranspiration are given in Table 3 on a monthly basis.

Table 3. Weather parameters considered for the estimation of reference evapotranspiration, (CROPWAT 8.0)

\begin{tabular}{|c|c|c|c|c|c|c|c|}
\hline $\begin{array}{l}\text { Country: } \\
\text { Italy }\end{array}$ & & & & & & & $\begin{array}{c}\text { Station: Sant } \\
\text { Arcangelo }\end{array}$ \\
\hline $\begin{array}{c}\text { Altitude: } \\
183 \mathrm{~m}\end{array}$ & \multicolumn{6}{|c|}{ Latitude: $40.99^{\circ} \mathrm{N}$} & $\begin{array}{c}\text { Longitude: } \\
16.80^{\circ} \mathrm{E}\end{array}$ \\
\hline \multirow[t]{2}{*}{ Month } & $\begin{array}{c}\text { Min } \\
\text { Temp }\end{array}$ & $\begin{array}{l}\text { Max } \\
\text { Temp }\end{array}$ & $\begin{array}{c}\mathrm{Hu}- \\
\text { midity }\end{array}$ & Wind & Sun & $\operatorname{Rad}$ & Eto \\
\hline & ${ }^{\circ} \mathrm{C}$ & ${ }^{\circ} \mathrm{C}$ & $\%$ & $\begin{array}{l}\mathrm{Km} / \\
\text { day }\end{array}$ & $\begin{array}{c}\text { hours/ } \\
\text { day }\end{array}$ & $\begin{array}{l}\mathrm{MJ} / \\
\mathrm{M}^{2} / \\
\text { day }\end{array}$ & $\mathrm{mm} /$ day \\
\hline January & 3.6 & 10.0 & 82 & 173 & 3.3 & 6.2 & 0.80 \\
\hline February & 4.6 & 11.7 & 81 & 173 & 4.0 & 8.7 & 1.14 \\
\hline March & 5.9 & 14.2 & 79 & 173 & 5.3 & 12.9 & 1.77 \\
\hline April & 8.5 & 17.8 & 77 & 173 & 6.7 & 17.4 & 2.63 \\
\hline May & 12.2 & 22.7 & 76 & 173 & 8.3 & 21.4 & 3.69 \\
\hline June & 15.4 & 27.0 & 75 & 173 & 9.7 & 24.0 & 4.60 \\
\hline July & 17.7 & 32.5 & 71 & 173 & 12.0 & 26.8 & 5.79 \\
\hline August & 17.9 & 32.3 & 71 & 173 & 11.2 & 24.0 & 5.33 \\
\hline September & 15.1 & 25.7 & 76 & 173 & 7.8 & 16.7 & 3.37 \\
\hline October & 11.9 & 20.4 & 79 & 173 & 5.6 & 11.1 & 2.02 \\
\hline November & 7.9 & 15.4 & 80 & 173 & 4.4 & 7.5 & 1.22 \\
\hline December & 5.0 & 11.2 & 83 & 173 & 3.2 & 5.6 & 0.80 \\
\hline Average & 10.5 & 20.1 & 77 & 173 & 6.8 & 15.2 & 2.76 \\
\hline
\end{tabular}

CROPWAT allows the development of irrigation schedules for different management conditions and the calculation of scheme water supply for varying crop patterns. The program can also be used to evaluate farmers' irrigation practices and to estimate crop performance under both rainfed and irrigated conditions.

All calculation procedures used in CROPWAT 8.0 are based on the two FAO publications of the Irrigation and Drainage Series, No. 56 "Crop Evapotranspiration Guidelines for computing crop water requirements" and No. 33 "Yield response to water". 
The development of irrigation schedules in CROPWAT is based on a daily soil-water balance using various userdefined options for water supply and irrigation management conditions. Scheme water supply is calculated according to the cropping pattern defined by the user, which include in this paper, up to 21 crops.

\section{Simulation of different irrigation scenarios and generation of crop response to water curves}

The crop response to water curves have been generated applying different irrigation scenarios in CROPWAT program starting from full irrigation that corresponds to maximum (optimal) yield and then reducing progressively irrigation input until reaching rainfed conditions. Soil water balance is calculated on a monthly basis and it is expressed in terms of water depletion in the effective root zone.

When the root zone water depletion (Dr), is lower than readily available water (RAW), which is predetermined fraction of total available water (TAW) and threshold for water stress, then ETc is considered through Ks-reduction coefficient (0-1), accounted for water depletion below optimum yield threshold (RAW) as shown in figure 2, Ks is calculated by the following formula (4):

$$
\mathrm{K}_{\mathrm{S}}=(\mathrm{TAW}-\mathrm{Dr}) /(\mathrm{TAW}-\mathrm{RAW}) \quad \mathrm{Eq}(4)
$$

where:

- Dr, Root Zone Soil Water Depletion

- TAW, Total Available Water

- RAW, Readily Available Water - a fraction of TAW and threshold for water stress

Whenever soil water depletion exceeds a predetermined optimum yield threshold of RAW (which can be considered either constant during the whole season or variable for different growth stages) crop evapotranspiration is adjusted for water stress conditions using Ks Equation (5):

$$
\mathrm{ET}_{\mathrm{a}}=\mathrm{ET}_{\mathrm{c}, \text { adj }}=\mathrm{K}_{\mathrm{s}^{*}} \mathrm{~K}_{\mathrm{c}^{*}} \mathrm{ETo}
$$

A simple, linear crop-water production function (CWPF) was applied to predict the reduction in crop yield when irrigation water was not adequate to cover crop water requirements and when crops suffer water stress Equation (6):

$$
\left(1-\mathrm{Y}_{\mathrm{a}} / \mathrm{Y}_{\mathrm{m}}\right)=\mathrm{K}_{\mathrm{y}^{*}}\left(1-\mathrm{ET}_{\mathrm{a}} / \mathrm{ET}_{\mathrm{c}}\right) \quad \mathrm{Eq}(6)
$$

where:

- $\mathrm{K}$ : yield response factor (dimensionless)

- $\mathrm{ET}_{\mathrm{a}}$ : actual crop evapotranspiration (mm/day)

- $\mathrm{ET}_{\mathrm{c}}^{\mathrm{a}}$ : maximum crop evapotranspiration ( $\left.\mathrm{mm} / \mathrm{day}\right)$

- $\mathrm{Y}_{\mathrm{a}}$ : actual yield $(\%)$

- $\mathrm{Y}_{\mathrm{m}}$ : maximum yield (100\%)
Figure 2. Water stress coefficient, Ks (Source: FAO 56, 1998)

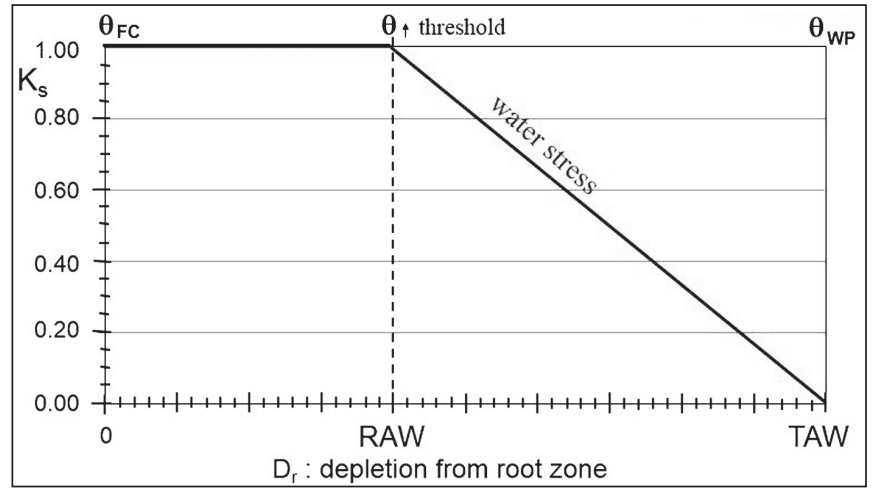

\section{Evapotranspiration (ETc)}

Crop evapotranspiration (ETc) is defined as "the amount of water lost by evapotranspiration process from disease-free, well-fertilized crops, grown in large fields under optimum soil water conditions, and achieving full production under the given climatic conditions" (FAO 56, 2004).

Estimation of crop evapotranspiration relies on the so-called two-step approach where, in the first step, a reference evapotranspiration (ETo) is determined and then, in the second step, the crop evapotranspiration (ETc), under standard conditions, is calculated as a product of reference evapotranspiration and crop coefficient (Kc) as Equation (7):

$\mathrm{ET}_{\mathrm{c}}=\mathrm{ET}_{0^{*}} \mathrm{~K}_{\mathrm{c}} \quad \mathrm{Eq}(7)$

The main factors affecting the crop evapotranspiration are:

- Weather parameters (radiation, air temperature, humidity and wind speed)

- Crop (type, variety, development stage)

- Management and environmental conditions (soil salinity, land fertility, application of fertilizers, the presence of impenetrable soil horizons, control of diseases and pests, soil management...) (R. Allen, L. Pereira, D. Raes, \& M. Smith, 1998).

The reference evapotranspiration term refers primarily to different climatic conditions, while the crop coefficient accounts mainly for the specific crop characteristics.

\section{RESULTS AND DISCUSSIONS}

\section{Irrigation water requirements:}

\section{Determination of the dry, normal and wet year:}

In order to estimate the rainfall deficit for irrigation water requirements, a statistical analysis needs to be made from long-term rainfall records( 30 years). Defined as the rainfall with a respectively 20,50 , and $80 \%$ probability of exceedance, representing a wet, normal and dry year. The three values are useful for the programming of irrigation supply and simulation of irrigation management conditions, especially the results of the dry year that are 
used for the determination of design of irrigation system capacity.

The precipitation with the probability occurrence of $80 \%$ refers to a dry period and it is considered for the estimation of irrigation requirements and calculation of specific continuous discharge after the determination of the cropping pattern. For the calculation of this probability of occurrence we used the following procedure:

An estimate of the respective rainfall data can be obtained by computing and plotting probabilities from the rainfall records. The different steps involved are:

Tabulate yearly rainfall totals for a given period (1981-2011).

Arrange data in descending order of magnitude (Table 4).

Tabulate plotting position according to: $F_{a}=100 \frac{m}{(N+1)} \quad \mathrm{Eq}(8)$

Where:

- $\mathrm{Fa}$ is the plotting position of the probability of exceedance (\%),

- $\mathrm{N}$ is the number of records (years)

- $\mathrm{m}$ is the rank number.

Table 4. Calculation of precipitation with the probability of exceedance of $80 \%$

\begin{tabular}{|c|c|c|c|c|}
\hline Rank & Year & $\begin{array}{c}\text { Annual } \\
\text { Precipitation } \\
(\mathrm{mm})\end{array}$ & $\mathrm{Fa}(\%)$ & \\
\hline 1 & 1990 & 737 & 3,23 & \\
\hline 2 & 1994 & 727 & 6,45 & \\
\hline 3 & 1984 & 645 & 9,68 & \\
\hline 4 & 1993 & 641 & 12,90 & \\
\hline 5 & 1987 & 629 & 16,13 & \\
\hline 6 & 1986 & 612 & 19,35 & $\begin{array}{c}\text { Wet Year } \\
\text { P20\% }=604,2 \mathrm{~mm}\end{array}$ \\
\hline 7 & 1991 & 575 & 22,58 & \\
\hline 8 & 1997 & 572 & 25,81 & \\
\hline 9 & 2000 & 566 & 29,03 & \\
\hline 10 & 2005 & 561 & 32,26 & \\
\hline 11 & 1981 & 556 & 35,48 & \\
\hline 12 & 1992 & 546 & 38,71 & \\
\hline 13 & 1983 & 543 & 41,94 & \\
\hline 14 & 1989 & 541 & 45,16 & \\
\hline 15 & 2001 & 540 & 48,39 & $\begin{array}{c}\text { Normal Year } \\
\text { P50\% }=524,8 \mathrm{~mm}\end{array}$ \\
\hline 16 & 2002 & 534 & 51,61 & \\
\hline 17 & 1982 & 525 & 54,84 & \\
\hline 18 & 2007 & 516 & 58,06 & \\
\hline 19 & 1988 & 512 & 61,29 & \\
\hline 20 & 1985 & 483 & 64,52 & \\
\hline 21 & 2006 & 483 & 67,74 & \\
\hline 22 & 2008 & 475 & 70,97 & \\
\hline 23 & 2004 & 470 & 74,19 & \\
\hline 24 & 1996 & 467 & 77,42 & $\begin{array}{c}\text { Dry Year P80\% }= \\
466,2 \mathrm{~mm}\end{array}$ \\
\hline 25 & 2003 & 466 & 80,65 & \\
\hline 26 & 1999 & 466 & 83,87 & \\
\hline 27 & 1998 & 438 & 87,10 & \\
\hline 28 & 1995 & 435 & 90,32 & \\
\hline 29 & 2009 & 404 & 93,55 & \\
\hline
\end{tabular}

$$
\begin{aligned}
& 30 \quad 2010 \quad 0357 \\
& P_{20 \%}=(20-22.58) \times \frac{(612-575)}{(19.35-22.58)}+575 \\
& P_{50 \%}=(50-51.61) \times \frac{(540-534)}{(48.39-51.61)}+534 \\
& P_{80 \%}=(80-80.65) \times \frac{(467-466)}{(77.42-80.65)}+466
\end{aligned}
$$

Using linear interpolation, we find the following values:

Determination of the monthly values for the dry year:

$$
P_{i, d r y}=P_{i, a v g} \frac{P_{d r y}}{P_{a v g}} \quad \text { Eq (9) }
$$

The determination of monthly values for the dry year is done according to the following relationship Equation 9:

Where:

: The monthly rainfall (dry year) for month $\mathrm{i}$.

: Average monthly rainfall for month $\mathrm{i}$.

: Average yearly rainfall ( $=534 \mathrm{~mm}$ ).

: Yearly rainfall for the dry year.

Table 5. Monthly precipitation values for the dry year

\begin{tabular}{|l|l|l|}
\hline Month & Pavg_year & Pdry_year \\
\hline 1 & 74 & 65 \\
\hline 2 & 64 & 56 \\
\hline 3 & 57 & 49 \\
\hline 4 & 37 & 32 \\
\hline 5 & 27 & 23 \\
\hline 6 & 21 & 19 \\
\hline 7 & 9 & 8 \\
\hline 8 & 17 & 15 \\
\hline 9 & 40 & 35 \\
\hline 10 & 51 & 45 \\
\hline 11 & 60 & 52 \\
\hline 12 & 77 & 67 \\
\hline Total & 534 & 466 \\
\hline
\end{tabular}

\section{Determination of the effective rainfall}

The Effective rainfall is divided two parts. The first part of the total rainfall infiltrates along the effective root depth and it is used by the plant to satisfy its related crop water requirements. The other part of rainfall is lost by leaf interception, evaporation, surface runoff and/or deep percolation. We choose the formula developed by the USDA Soil Conservation Service for the estimation of effective rainfall on a monthly basis. 
$P_{\text {eff }}=P_{\text {month }} *\left(125-0.2 * P_{\text {month }}\right) / 125$

$P_{\text {eff }}=125+0.1 * P_{\text {month }}$ for $\mathrm{P}_{\text {month }}<=250 \mathrm{~mm}$, and for $P_{\text {month }}>250 \mathrm{~mm}$.
For decade (10 days) estimations are applied the following formulas:

$P_{e f f}=P_{d e c} *\left(125-0.6 * P_{d e c}\right) / 125$

for $\mathrm{P}_{\mathrm{dec}}<=(250 / 3) \mathrm{mm}$, and

$P_{\text {eff }}=125 / 3+0.1 * P_{d e c}$

for $\mathrm{P}_{\mathrm{dec}}>(250 / 3) \mathrm{mm}$.

The results of effective rainfall estimation for the study area are shown in the table below (Table 6) taken from CROPWAT software:

Table 6. Monthly effective rainfall values for the average year (Created By Cropwat Software)

\begin{tabular}{|c|c|c|}
\hline Station: Sant Arcangelo & & $\begin{array}{c}\text { Eff.rain method } \\
\text { [USDA S.C.Method] }\end{array}$ \\
\hline \multirow[t]{2}{*}{ Months } & Rain & Eff.rain \\
\hline & $\mathrm{mm}$ & $\mathrm{mm}$ \\
\hline January & 74.0 & 65.2 \\
\hline February & 74.0 & 57.4 \\
\hline March & 74.0 & 51.8 \\
\hline April & 74.0 & 34.8 \\
\hline May & 74.0 & 25.8 \\
\hline June & 74.0 & 20.3 \\
\hline July & 74.0 & 8.9 \\
\hline August & 74.0 & 16.5 \\
\hline September & 74.0 & 37.4 \\
\hline October & 74.0 & 46.8 \\
\hline November & 74.0 & 54.2 \\
\hline December & 74.0 & 67.5 \\
\hline Total & 534.0 & 486.9 \\
\hline
\end{tabular}

Net irrigation requirements

Net irrigation requirements (NIR) represent the amount of water that crops need to satisfy the water losses by crop evapotranspiration after subtracting the amount of effective rainfall (Peff) Equation (10).

$$
N I R=E T_{c}-P_{\text {eff }} \quad \text { Eq (10) }
$$

NIR and GIR should be estimated for both average(Table 7) and dry year(Table 8): Figure 3and 4also show the NIR and GIR for each crop for average and dry year respectively.

Gross irrigation requirements

To account losses and irrigation efficiency we have to apply gross irrigation requirements; the gross irrigation requirement (GIR) is the amount of irrigation water that should be applied at the head of irrigation field in order to satisfy the NIR, it is obtained by dividing the amount of the net irrigation requirement (NIR) for each crop by the application efficiency (Ea) of the irrigation method Equation(11).

$$
G I R=\frac{N I R}{E_{a}} \quad \operatorname{Eq}(11)
$$

In this study, we are going to account for different efficiencies $90 \%$ and $75 \%$ which correspond to drip irrigation and sprinkler irrigation respectively.

\section{For average year}

\begin{tabular}{|c|c|c|c|c|c|}
\hline & Etc $(\mathrm{mm})$ & Effrain (mm) & $\begin{array}{l}\text { Net Irrreq } \\
(\mathrm{mm})\end{array}$ & $\mathrm{Ea}$ & GIR (mm) \\
\hline Pepper & 579 & 104 & 475 & 0,9 & 527,8 \\
\hline E.Potato & 221,5 & 138,7 & 82,8 & 0,75 & 110,4 \\
\hline C.Potato & 367,4 & 109,3 & 258,1 & 0,75 & 344,1 \\
\hline Soybean & 515,1 & 99,3 & 415,8 & 0,9 & 462,0 \\
\hline $\begin{array}{l}\text { Sweet } \\
\text { melon }\end{array}$ & 413,9 & 86,5 & 327,4 & 0,9 & 363,8 \\
\hline Tomato & 619,1 & 99,1 & 520 & 0,9 & 577,8 \\
\hline $\begin{array}{c}\text { Sugarbeet } \\
\text { autumn }\end{array}$ & 604,9 & 194,6 & 410,3 & 0,75 & 547,1 \\
\hline $\begin{array}{c}\text { Sugarbeet } \\
\text { Springs }\end{array}$ & 734,8 & 129 & 605,8 & 0,75 & 807,7 \\
\hline Artichoke & 632,7 & 311,6 & 321,1 & 0,75 & 428,1 \\
\hline Carrot & 355,6 & 157,8 & 197,8 & 0,75 & 263,7 \\
\hline $\begin{array}{l}\text { Cereal } \\
\text { wheat }\end{array}$ & 429,4 & 198,3 & 231,1 & 0,75 & 308,1 \\
\hline Eggplant & 577,3 & 87,5 & 489,8 & 0,75 & 653,1 \\
\hline Lettuce & 135,5 & 135,5 & 0 & 0,9 & 0,0 \\
\hline Maize & 542,4 & 80,4 & 462 & 0,75 & 616,0 \\
\hline Sunflower & 512,5 & 89,7 & 422,8 & 0,75 & 563,7 \\
\hline $\begin{array}{l}\text { Broad } \\
\text { bean }\end{array}$ & 299,2 & 186,9 & 112,3 & 0,9 & 124,8 \\
\hline Citrus & 738,3 & 305,3 & 433 & 0,9 & 481,1 \\
\hline Cherry & 826,5 & 249,3 & 577,2 & 0,9 & 641,3 \\
\hline Olive tree & 677,5 & 244,2 & 433,3 & 0,9 & 481,4 \\
\hline Peach & 536,5 & 181,7 & 354,8 & 0,9 & 394,2 \\
\hline $\begin{array}{l}\text { Wine } \\
\text { grapes }\end{array}$ & 531,9 & 178,2 & 353,7 & 0,9 & 393,0 \\
\hline
\end{tabular}

Table 7. Seasonal ETc, Peff, NIREa and GIR for average year 
Figure 3. Seasonal NIR and GIR for average year

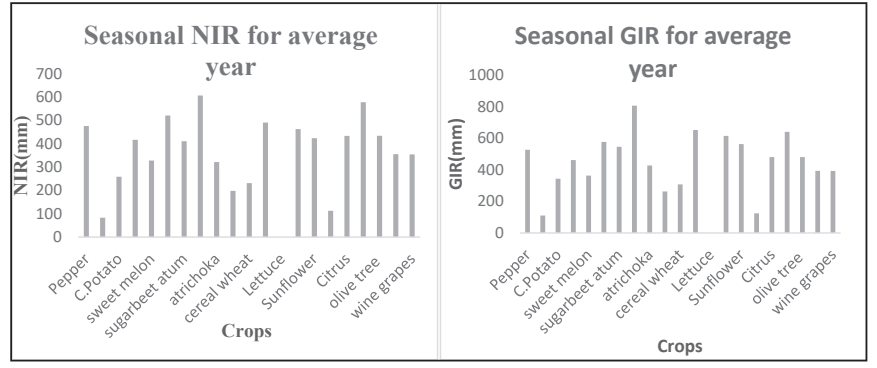

For dry year

Table 8 Seasonal ETc, Peff, NIREa and GIR for dry year

\begin{tabular}{|c|c|c|c|c|c|}
\hline & Etc(mm) & $\begin{array}{c}\text { Effrain } \\
(\mathrm{mm})\end{array}$ & $\begin{array}{c}\text { Net } \\
\text { Irrreq(mm) }\end{array}$ & Ea & GIR (mm) \\
\hline Pepper & 579 & 91,5 & 487,5 & 0,9 & 541,7 \\
\hline E Potato & 221,5 & 127,3 & 94,2 & 0,75 & 125,6 \\
\hline C potato & 367,4 & 99,5 & 267,9 & 0,75 & 357,2 \\
\hline Soybean & 515,1 & 89,2 & 425,9 & 0,9 & 473,2 \\
\hline Sweet melon & 413,9 & 77,3 & 336,6 & 0,9 & 374,0 \\
\hline Tomato & 619,1 & 88,5 & 530,6 & 0,9 & 589,6 \\
\hline Sugarbeet autumn & 604,9 & 178,4 & 426,5 & 0,75 & 568,7 \\
\hline Sugarbeet Springs & 734,8 & 117 & 617,8 & 0,75 & 823,7 \\
\hline Atrichoka & 632,7 & 292,7 & 340 & 0,75 & 453,3 \\
\hline Carrot & 355,6 & 146,2 & 209,4 & 0,75 & 279,2 \\
\hline Cereal wheat & 429,4 & 185 & 244,4 & 0,75 & 325,9 \\
\hline Eggplant & 577,3 & 77,1 & 500,2 & 0,75 & 666,9 \\
\hline Lettuce & 135,5 & 135,2 & 0,3 & 0,9 & 0,3 \\
\hline Maize & 542,4 & 70,8 & 471,6 & 0,75 & 628,8 \\
\hline Sunflower & 512,5 & 80,7 & 431,8 & 0,75 & 575,7 \\
\hline Broad bean & 299,2 & 176,1 & 123,1 & 0,9 & 136,8 \\
\hline Citrus & 738,3 & 284,2 & 454,1 & 0,9 & 504,6 \\
\hline Cherry & 826,5 & 225 & 601,5 & 0,9 & 668,3 \\
\hline Olive tree & 677,5 & 224,1 & 453,4 & 0,9 & 503,8 \\
\hline Peach & 536,5 & 171,7 & 364,8 & 0,9 & 405,3 \\
\hline Wine grapes & 531,9 & 161 & 370,9 & 0,9 & 412,1 \\
\hline
\end{tabular}

Figure 4. Seasonal NIR and GIR for dry year

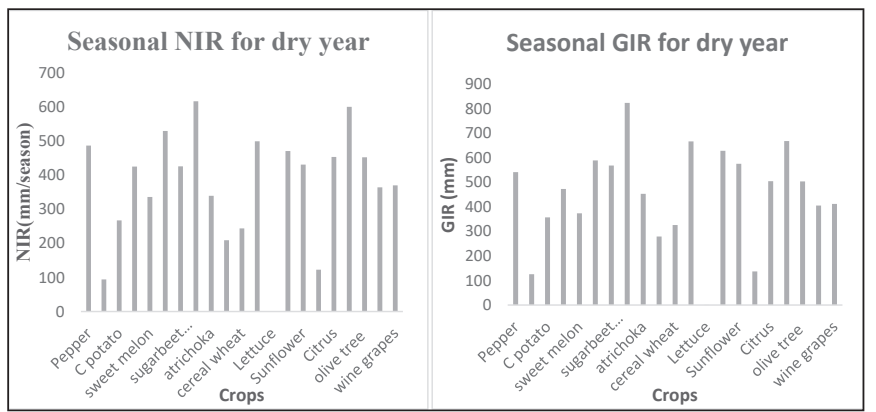

Salt balance

In an irrigation project, the determination of the irrigation requirements should take into account the leaching fraction necessary to remove salts from the soil. The simplified salt balance involves several assumptions:

- The only source of salt is irrigation water.

- No capillary rise.

- No deep percolation and runoff (efficient irrigation).

- All salts are highly soluble and do not precipitate.

- The amount of salt supplied by rainfall is negligible.

- The amount of salts supplied by fertilizers and exported by crops are negligible.

The electrical conductivity of irrigation water in the study area is $\mathrm{EC}_{\mathrm{iw}}=0.8 \mathrm{dS} / \mathrm{m}$. So, the average concentration of salts in irrigation water is:

$0.8^{*} 0.64=0.512 \mathrm{Kg} / \mathrm{m}^{3}\left(640 \mathrm{mg} / \mathrm{l}=0.640 \mathrm{Kg} / \mathrm{m}^{3}=1 \mathrm{dS} / \mathrm{m}\right)$.

The calculation of the quantity of water supplied by irrigation is carried out from the value of the gross irrigation requirement for an average year, and it is about $4196.24 \mathrm{~m}^{3} /$ ha/year.

$\mathrm{QS}_{\mathrm{iw}}=\mathrm{Q}_{\mathrm{iw}} * \mathrm{~S}_{\mathrm{iw}}$

where

$\mathrm{QS}_{\mathrm{iw}}$ : Quantity of salts in irrigation water ( $\left.\mathrm{kg} / \mathrm{ha} / \mathrm{year}\right)$

$\mathrm{Q}_{\text {iw }}$ : Quantity of water supplied ( $\mathrm{m}^{3} /$ ha/year)

Siw : Salinity of water $\left(\mathrm{kg} / \mathrm{m}^{3}\right)$

The quantity of salt provided by irrigation water is $4196.24 * 0.512=2148.47 \mathrm{~kg} / \mathrm{ha} /$ year

The soil porosity is given by the following formula:

where

The bulk density of soil $\rho_{h}$ is $1247 \mathrm{Kg} / \mathrm{m}^{3} \quad$ So, $\mathrm{n}=0,52$ The specific density of soil $\rho_{s}$ is $2600 \mathrm{Kg} / \mathrm{m}^{3}$.

The total volume of one hectare of land equals $10000 \mathrm{~m}^{2 *}$ soil depth (m).

Knowing the effective soil depth is $0.7 \mathrm{~m}$, the total volume of soil is $7000 \mathrm{~m}^{3}$.

If the porosity is equal to 0.52 , that means that $52 \%$ of the total volume of soil is occupied by pores. So, the amount of water necessary to bring the soil to saturation is

$$
7000 \mathrm{~m}^{3} * 0.52=3640 \mathrm{~m}^{3} / \mathrm{ha}
$$

Considering the cropping pattern and the crop salt tolerance (FAO No.29 revised), it is acceptable to reduce yield by $25 \%$ which correspond to EC of soil saturation paste equal to: $4 \mathrm{dS} / \mathrm{m}(4 * 0.640=2.56 \mathrm{~kg} \mathrm{salt} / \mathrm{m} 3)$.

$3640\left(\mathrm{~m}^{3} /\right.$ ha/year $) * 2.56\left(\mathrm{Kg} / \mathrm{m}^{3}\right)=9318.4 \mathrm{Kg} \mathrm{salt} / \mathrm{ha}$

The number of years required to reach this level of salinity is:

$$
N=\frac{9318.4(\mathrm{~kg} / \mathrm{ha})}{2148.47(\mathrm{~kg} / \mathrm{ha} / \mathrm{an})}=4.34 \text { years }
$$


So, we could have some salinity problems after about 4.3years of irrigation. In reality, it is expected that during the winter season, the rainfall will remove the salts from the soil. Otherwise we should take into account the determination of leaching requirements then also thinks about the necessity of a drainage system.

\section{CONCLUSIONS}

The one-years long research developed both theoretical significance of the discipline and applied methodology. Firstly, a major contribution of the paper is the estimation of the CWR and IWR for some selected crops as well as developing cropping pattern for the study area using CROPWATv8.0. We had seen IWR is very low from November to April (wintertime) due to higher rainfall intensity in these months and from May to October a considerable amount of water is required for irrigation. Secondly ,the total effective rainfall estimated by CROPWAT was $486.9 \mathrm{~mm}$. The results showed that the lowest values of effective rainfall were in July and August 8.9-16.5 respectively(Summertime). Finally, By studying the Salt balance, we have seen some salinity problems after about 4.3years of irrigation but in reality, on the winter season the rainfall will remove the salt from the soil.

\section{REFERENCES}

Aggarwal, P. K., Kalra, N., Chander, S., \& Pathak, H. J. A. s. (2006). InfoCrop: a dynamic simulation model for the assessment of crop yields, losses due to pests, and environmental impact of agro-ecosystems in tropical environments. I. Model description. $89(1), 1-25$

Allen, R., Pereira, L., Raes, D., \& Smith, M. (1998). Guidelines for computing crop water requirements-FAO Irrigation and drainage paper 56, FAO-Food and Agriculture Organisation of the United Nations, Rome (http://www. fao. org/docrep) ARPAV (2000), La caratterizzazione climatica della Regione Veneto, Quaderni per. Geophysics, 156, 178.

Allen, R. G., Pereira, L. S., Raes, D., \& Smith, M. J. F., Rome. (1998). Crop evapotranspiration-Guidelines for computing crop water requirements-FAO Irrigation and drainage paper 56. 300(9), D05109.

Bruinsma, J. (2009). The resource outlook to 2050: by how much do land, water and crop yields need to increase by 2050. Paper presented at the Expert meeting on how to feed the world in.

Chang, H., Knight, C. G., Staneva, M. P., \& Kostov, D. J. G. (2002). Water resource impacts of climate change in southwestern Bulgaria. 57(3), 159-168.

Dhungana, P., Eskridge, K. M., Weiss, A., \& Baenziger, P. J. A. S. (2006). Designing crop technology for a future climate: an example using response surface methodology and the CERES-Wheat model. 87(1), 63-79.

Dockerty, T., Lovett, A., Appleton, K., Bone, A., Sünnenberg, G. J. A., Ecosystems, \& Environment. (2006). Developing scenarios and visualisations to illustrate potential policy and climatic influences on future agricultural landscapes. 114(1), 103-120.

Dubois, O. (2011). The state of the world's land and water resources for food and agriculture: managing systems at risk: Earthscan.

Gbetiobouo, G., Hassan, R. J. M. A. E., Faculty of Natural, \& Agricultural Sciences, U. o. P., Pretoria. (2004). Economic Impact of Climate Change on Major South African Field Crops: A Ricardian Approach.

Hanjra, M. A., \& Qureshi, M. E. J. F. p. (2010). Global water crisis and future food security in an era of climate change. 35(5), 365-377.

Harle, K., Howden, S., Hunt, L. P., \& Dunlop, M. J. A. S. (2007). The potential impact of climate change on the Australian wool industry by $2030.93(1-3), 61-89$.

HerreraఏPantoja, M., \& Hiscock, K. J. H. P. A. I. J. (2008). The effects of climate change on potential groundwater recharge in Great Britain. 22(1), 73-86.

Hoogenboom, G. J. A., \& meteorology, f. (2000). Contribution of agrometeorology to the simulation of crop production and its applications. 103(1-2), 137-157.

Kang, Y., Khan, S., \& Ma, X. J. P. i. n. S. (2009). Climate change impacts on crop yield, crop water productivity and food security-A review. 19(12), 1665-1674.

Magadza, C. H. D. J. E. M., \& Assessment. (2000). Climate change impacts and human settlements in Africa: prospects for adaptation. 61(1), 193-205.

Margat, J., Frenken, K., \& Faurès, J.-M. (2005). Key water resources statistics in AQUASTAT: FAO's global information system on water and agriculture. Intersecretariat working group on environment statistics (IWG-Env), international work session on water statistics, Vienna.

Pereira, L. S., \& Alves, I. (2005). CROP WATER REQUIREMENTS. In D. Hillel (Ed.), Encyclopedia of Soils in the Environment (pp. 322-334). Oxford: Elsevier.

Report, F. J. A. (2017). The future of food and agriculture-Trends and challenges: Food and Agriculture Organisation Rome.

Stöckle, C. O., Donatelli, M., \& Nelson, R. J. E. j. o. a. (2003). CropSyst, a cropping systems simulation model. 18(3-4), 289-307.

Wilby, R. L., \& Harris, I. J. W. r. r. (2006). A framework for assessing uncertainties in climate change impacts: Low scenarios for the River Thames, UK. 42(2). 
